\title{
二次元PIVに基うく速度場・压力場の三次元再構成に関する基礎研究 \\ Basic Research on Three-Dimensional Reconstruction of Velocity Field and Pressure Field Based on Two-Dimensional PIV.
}

\author{
○学 佐藤 明人（新潟大院）正藤沢 延行（新潟大工）
}

Akito Satoh, Graduate school of Niigata university 8050 Ikarashi2, Niigata, 950-2181

Nobuyuki Fujisawa, Niigata University,

Key Words : Flow Visualization, PIV, Measurement, Velocity, Pressure, Three-dimensional Flow

\section{1. 緒言}

給湯機や暖房器具などに使われる燃焼装置について は、燃焼効率の改善や低騒音化等を目的とした熱流動 の解析研究が進められている。しかしながら、缶体内 部における燃焼を伴う熱流動現象の計測は、現在のと ころ極めて困難な課題であるため、その詳細を十分に 理解するまで至っていない。このため、燃焼装置の設 計開発においては、水模型を用いた流れ場の可視化・ 速度計測によって流動現象を把握する方法がしばしば 採られている。その際、燃焼器内部の流れは、強い 3 次元性流を伴うため、空間内の速度 3 成分の分布を計 測する必要がある。著者ら ${ }^{(1)}$ は、先に、2 次元PIVを複 数の断面に適用し、さらに連続の式を用いて、時間平 均 3 次元流れ場を明らかにする方法を示した。しかし ながら、測定データの空間解像度の制約から内部流の 詳細を把握するまでは至っていない。

本研究では、燃焼器内部の流れ場を十分な空間解像 度でPIV 計測し、3 次元平均速度場の詳細を明らかに することを目的とする。さらに、計測された速度場か ら压力場を評価する方法についても検討する。

\section{2. 実験装置及び方法}

2. 1 燃焼装置の水模型と可視化 図 1 に内部流動 計測に用いた実験装置の概略を示す。これは、実機燃 焼装置を水実験用にモデル化したものであり、燃焼容 器の寸法は、縦横高さがそれぞれ、200mm、200mm、300m であり、流入口および流出口内径は $75 \mathrm{~mm}$ とした。実機 模型においては、燃焼ガスの組成とその燃焼温度（= 1500K）を考虑すると、燃焼時のレイノルズ数Re(=UD/ $v)=10^{4}$ 程度であった。したがって、同ーレイノルズ数 における模型実験を行うため、流入口における断面平 均流速は、U=0.11m/sとした。ただし、模型装置への水 の供給にはポンプを用い、流量の測定はオリフィス流 量計で行った。

流れの可視化には、水流に対し良好な追従性を示す ナイロン粒子(平均粒径 $0.1 \mathrm{~mm}$, 比重 1.02) を用い、それ を装置内に予め供給しておいた。照明にはストロボス コープを用い、そこで発生させた光を光ファイバーを 介してシリンドリカルレンズの付いた光学系に導き、 シート状(厚さ $7 \mathrm{~mm}$ )に照射できるようにした。撮影に はモノクロ CCDカメラ (画像解像度 $768 X 494$ ピクセル、 256 階調)を用いた。ストロボの発光タイミングは、こ の CCD メラから出力される $30 \mathrm{~Hz}$ の垂直同期信号を 用いて制御した。この画像は、直接フレームグラバで

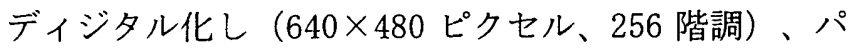

ーソナルコンピュータ内のフレームメモリに格納した。 2. 2 PIVIよる2次元速度場解析 以上のようにし て得られた画像データの連続する 2 枚に対して、輝度 差累積法を用いて相関計算を行った。計算条件は、画 像サイズ $640 \times 480$ 、ベクトル数 $65 \times 49$ 、相関領域 $23 \times 23$ 、 探索領域12x12であった。なお、計測精度を向上させ るため、サブピクセル解析も行っている。本実験では 高解像度での計測を行うため、300 $\mathrm{mmx} 200 \mathrm{~mm}$ の計測断面 を、縦4分割横4分割の計16枚に分割してそれぞれ別に 撮影し、速度場解析の後に再び全速度場の合成を行っ た。このとき、测定位置を高精度で測定するため、力 メラは 3 次元トラバース装置に固定した。

2. 3 面外方向速度成分の計算 非圧縮性流体に対す る連続の式は、以下の通りである。

$\frac{\partial u}{\partial x}+\frac{\partial v}{\partial y}+\frac{\partial w}{\partial z}=0 \quad(\rho=$ const $)$

この式から、3 次元空間内の速度 $u, v$ が与えられれば、 壁面での境界条件として $\mathrm{w}=0$ を用いて、w の分布を 決定することが可能である。すなわち $\mathrm{z}=0 \mathrm{~mm}$ 及び $200 \mathrm{~mm}$ のとき $\mathrm{w}=0$ を用いるものとする。これは、本 実験で用いた水模型が容器型であるという性質上可能 になったものである。これを 2 次元速度場解析の結果 に適用して 3 次元空間での $\mathrm{w}$ を得た。なお、 $\mathrm{z}$ 方向の 積分に伴う累積誤差の影響を減らすため、適宜補間と 平均化の処理(2)を行った。

2. 4 圧力の計算 圧力分布の算出には、差分化し たナビエ・ストークス方程式を用いた。まず、各格子 点における $\mathrm{x}$ 方向の圧力勾配

$\frac{\partial P}{\partial x}=\rho\left\{v\left(\frac{\partial^{2} u}{\partial x^{2}}+\frac{\partial^{2} u}{\partial y^{2}}+\frac{\partial^{2} u}{\partial z^{2}}\right)-u \frac{\partial u}{\partial x}-v \frac{\partial u}{\partial y}-w \frac{\partial u}{\partial z}\right\}$ (2)

ならびに $\mathrm{y}, \mathrm{z}$ 方向の圧力勾配を同様な式からそれぞれ 求め、これを基準となる格子点から順に数值積分した。 積分経路は、今市ら ${ }^{(3)}$ の方法を三次元に拡張して適用 した。すなわち、考えられる6通りの経路を全て計算 し、その平均值を積分結果とした。

\section{3.実験結果およひ考察}

図 2 は、PIVによって計測された $\mathrm{x}, \mathrm{y}$ 平面内の速度成 分 $\mathrm{u}, \mathrm{v}(\mathrm{a})$ と、測定データと連続の式から解析的に求め た $\mathrm{y}, \mathrm{z}$ 平面内の速度成分 $\mathrm{v}, \mathrm{w}(\mathrm{b})$ の一例を示す。この図 は、時系列的に得られた 300 枚の速度場を重ね合わ せて得た時間平均速お分布である。この図から、流出 口からの噴流がその対向壁面に衝突した後、壁面に沿 って流れ、さらに容器内で再循環領域を形成したのち、

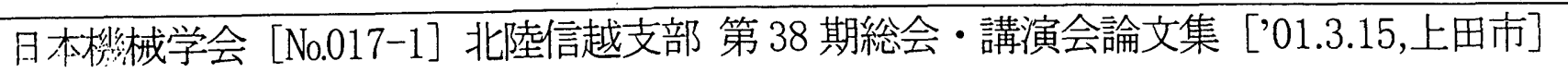


流出口に至ることがわかる。また、速度の小さい再循 睘領域は容器全域に広がっていることがわかる。

図 3 は、3 次元速度場情報から圧力を計算する際に、 容器中央と流入口、流出口の 3 箇所を積分の開始点に とったときの、それぞれの計算結果を比較したもので ある。ただし、その比較結果は、缶体の中央断面にお ける対向壁面上である。ここで示す圧力值 $\mathrm{Cp}$ は、基 準圧力として流入口での静压、代表速度として流入口 速度を用いた。本実験結果によると、流入口付近を除 く全領域で圧力の計算結果が積分開始点の位置に依存 しないことがわかる。

図 4 は、容器中央の $\mathrm{xy}$ 断面(a) と対向壁面近くの $\mathrm{yz}$ 断面上における $\mathrm{Cp}$ の分布を示す。なお、積分の開始 点は噴流の入り口とした。この結果から、噴流が壁面 に衝突している場所で圧力が高く、速度の小さい再循 環領域に低圧領域が広がっていることがわかる。

\section{4. 熘言}

燃焼装置内部全域にわたる時間平均 3 次元速度場を、 PIV ならびに連続の式を用いて再構成した。さらに、 そこで得られた三次元速度場情報をもとに圧力場を算 出する方法を示し、これを缶体に適用した。

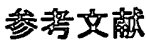

（1）佐藤、藤沢、高野、時田，日本機械学会北陸信越 部第 37 期講演会 $(2000-3), \mathrm{p} 321-322$

(2)N.Wang;W.Limberg, Exp.Fluids, 27(1998), $351-358$.

(3)今市、近江，日本機械学会論文集（B 編） 48 巻 436 号(昭 57-12), p2449-2459.

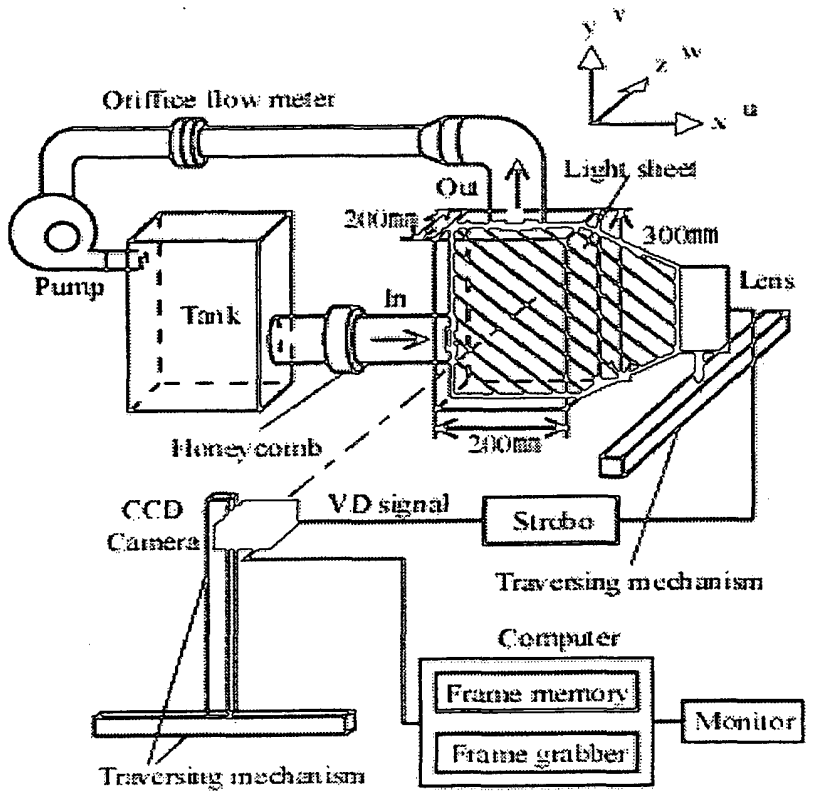

Fig1 Experimental Setup

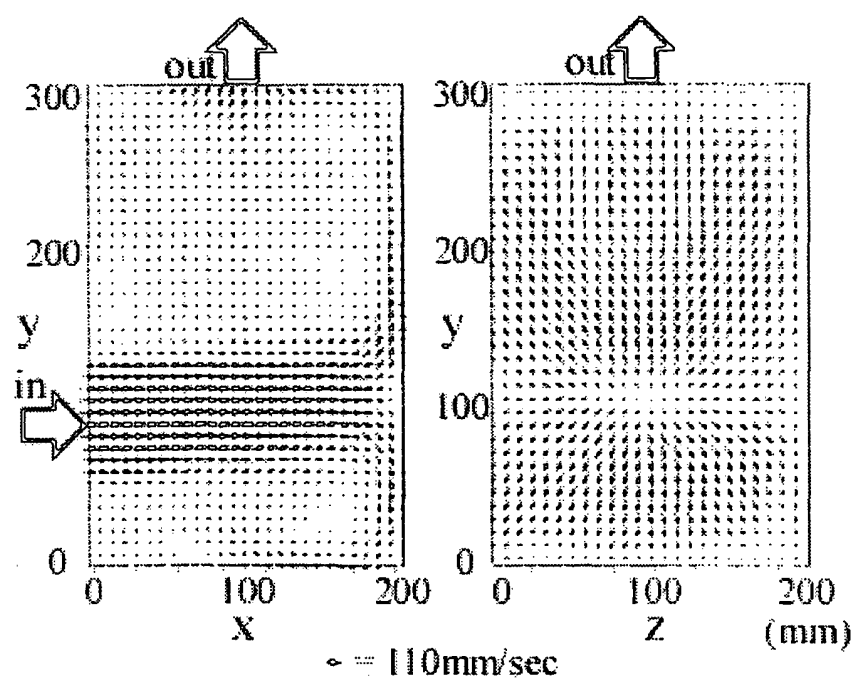

(a) $\mathrm{z}=100 \mathrm{~mm}$ (b) $\mathrm{x}=190 \mathrm{~mm}$

Fig2 Reconstructed Two-Dimensional Velocity Vectors

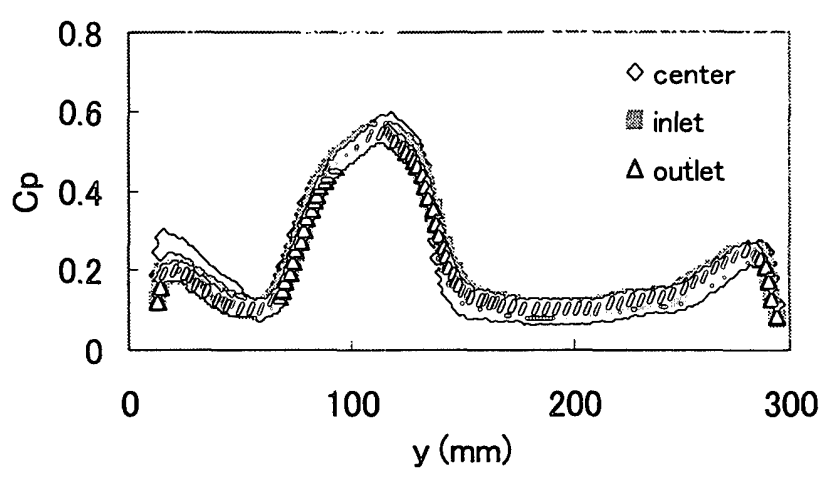

Fig3 Calculated Pressure Distributions At $x=200 \mathrm{~mm}, z=100 \mathrm{~mm}$

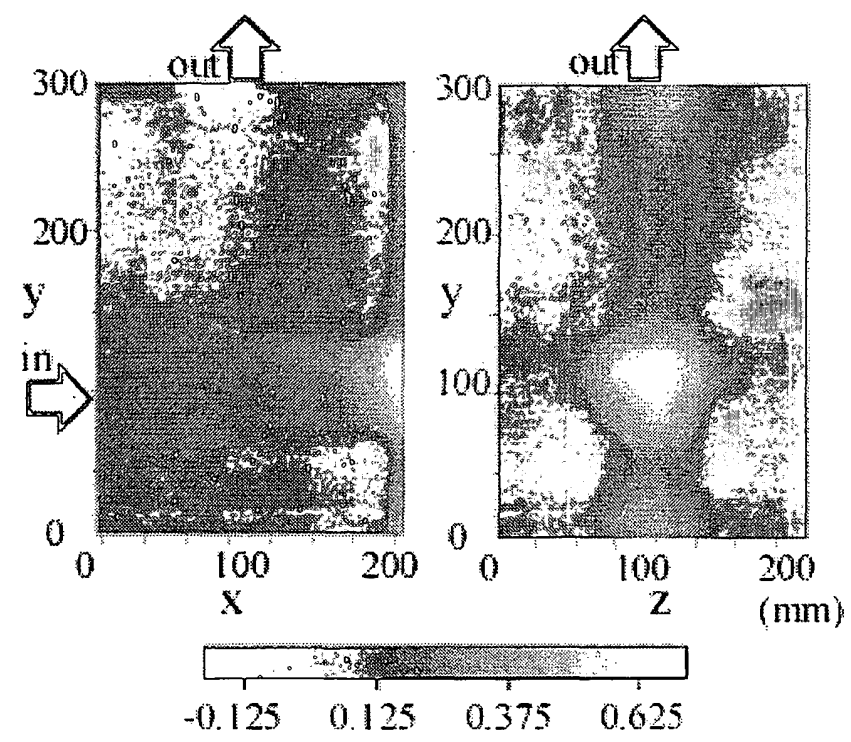
(a) $\mathrm{z}=100 \mathrm{~mm}$
(b) $x=190 \mathrm{~mm}$

Fig4 Distributions of $\mathrm{Cp}$ 